\title{
Risk of Infection with Methotrexate Therapy in Inflammatory Diseases: A Systematic Review and Meta-Analysis
}

\author{
Ammar Ibrahim ${ }^{1, *}$, Mohammed Ahmed ${ }^{1}$, Richard Conway ${ }^{2}(-)$ and John J. Carey ${ }^{3}(\mathbb{C}$ \\ 1 Department of Medicine, National University of Ireland Galway, Galway, Ireland; jamaleldeen@gmail.com \\ 2 Department of Rheumatic Diseases, St. James's University Hospital, Dublin, Ireland; \\ drrichardconway@gmail.com \\ 3 Department of Rheumatic Diseases, Galway University Hospitals, Galway, Ireland; \\ john.j.carey@nuigalway.ie \\ * Correspondence: ammar.ibrahim@nuigalway.ie; Tel.: +35-38-3417-3116
}

Received: 16 November 2018; Accepted: 15 December 2018; Published: 21 December 2018

\begin{abstract}
The aim of this study was to determine the risk of infection in adults with inflammatory rheumatic diseases (IRDs) treated with methotrexate. We performed a systematic review and meta-analysis of randomized controlled trials (RCTs) assessing methotrexate versus placebo in adults using MEDLINE, EMBASE, and CENTRAL databases from 1980 to August 2017. The primary outcome was the risk of infection associated with methotrexate therapy. We chose a random effect model to summarize adverse event outcomes as risk ratios (RRs) and related $95 \%$ confidence intervals ( $95 \%$ CI). Twelve RCTs (total patients 1146) met the inclusion criteria for our main analysis, and ten for risk of serious infection (total patients 906). Overall, methotrexate was associated with increased risk of infection in rheumatoid arthritis (RA) (RR: $1.25 ; 95 \%$ CI, 1.01-1.56; $p=0.04 ; I^{2}=0 \%$ ), but not in other non-RA IRD populations. There was no increased risk of total infections (RR: $1.14 ; 95 \% \mathrm{CI}$, $0.98-1.34 ; p=0.10 ; I^{2}=0 \%$ ) or serious infections (RR: $0.76 ; 95 \%$ CI $0.11-5.15 ; p=0.78 ; I^{2}=0 \%$ ) in all included IRDs. Conclusively, methotrexate use in IRDs is associated with a higher risk of all infections in RA, but not in other non-RA (IRD) populations. There is no increased risk of serious infections.
\end{abstract}

Keywords: methotrexate; infections and arthritis; inflammation; DMARDs

\section{Introduction}

Methotrexate is a commonly prescribed medication which primarily inhibits DNA synthesis [1,2]. It is highly efficacious and is thus the anchor therapy in the management of rheumatoid arthritis (RA) and a primary therapeutic choice in many other inflammatory and rheumatic conditions [3-7]. Serious side effects have been ascribed to methotrexate therapy including bone marrow suppression, pulmonary disease, liver fibrosis, and infection [8-11]. Recent studies determined that the risk of pulmonary disease and liver fibrosis is lower than previously believed [8-11].

Studies report an association of infections with specific rheumatic conditions such as RA, or with immune-suppressant medications used to treat these conditions, which may lead to poorer outcomes or death [12-15]. This may be true for some therapies, particularly biologic medications [16]. A recent review of multiple RA cohorts showed rates of hospitalized infection between 1.14 and 1.62 per 100 patients per annum [17]. Infection is the third leading cause of death in RA populations [18]. The risk of infectious adverse events with methotrexate therapy in inflammatory rheumatic diseases (IRDs) is unknown, as published studies report inconsistent results [12,19-23]. Some observational studies show that methotrexate increases the risk [19-21], while others do not [12,22,23]. Recent 
meta-analyses show an increased risk of infectious lung disease in RA [8], but not in non-RA IRD populations [24]. Validating and quantifying the risk is critical to support appropriate decision-making in clinical practice. Therefore, we undertook a systematic review and meta-analysis to clarify the risk of infection, serious infection, and death from infection in patients treated with methotrexate for inflammatory rheumatic diseases (IRDs).

\section{Materials and Methods}

\subsection{Data Sources and Searches}

A systematic search of the English language literature from 1980 to August 2017 was performed using the following three major databases: MEDLINE, EMBASE, and CENTRAL. A search was also performed for previous reviews and meta-analyses, and the bibliographies of all included studies. Multiple search terms related to the population of relevant inflammatory rheumatic diseases (IRDs) and the intervention "methotrexate" were used and were linked with appropriate Boolean operators such as "OR" and "AND". The detailed search strategies for the databases are provided in the supplement Table S1.

\subsection{Study Selection}

An initial screen for the eligibility of retrieved articles was performed based on the title and abstract in duplicate. Subsequently, full text articles considered for inclusion were retrieved and examined by two separate authors (A.I. and M.A.) independently and in duplicate, using pre-specified inclusion and exclusion criteria.

The inclusion criteria were (1) randomized controlled trials of adult human subjects ( $\geq 18$ years of age) with rheumatic arthritic conditions including osteoarthritis, inflammatory connective tissue diseases, and inflammatory diseases that can overlap with rheumatic conditions, specifically inflammatory bowel disease and psoriasis; (2) published in the English language; (3) studies that had at least two arms, with one arm receiving methotrexate alone, and another arm receiving placebo alone or some other intervention not known to increase infection risk; (4) studies of at least 12 weeks duration but without a sample size restriction; and (5) studies that assessed modern conventional doses of methotrexate ranging between 2.5 and $25 \mathrm{mg}$ per week administered weekly by oral, subcutaneous, or intramuscular routes.

The exclusion criteria were (1) nonrandomized or observational studies; (2) studies reported in a non-English language; (3) trials that did not clearly report infectious adverse events; (4) studies that assessed high-dose methotrexate (>25 mg per week); (5) studies using methotrexate in combination with other immunosuppressive medication such as long-term corticosteroids, biologic or non-biologic disease-modifying anti-rheumatic drugs (DMARDs); and (6) studies comparing methotrexate to other immunosuppressive medications. We did not exclude trials allowing non-immunosuppressive stable concomitant drug therapy, such as paracetamol or non-steroidal anti-inflammatory drugs (NSAIDs), or studies including short-term rescue corticosteroid therapy (in a dose of less than $15 \mathrm{mg}$ per day) for treating disease flares.

\subsection{Data Extraction and Quality Assessment}

Data were extracted independently and in duplicate by two authors (A.I. and M.A.), utilizing a form developed by The Cochrane Consumers and Communication Group (2016). Both authors (A.I. and M.A.) independently assessed the methodological quality of randomized controlled trials (RCTs) within and across studies using The Cochrane Collaboration's risk of bias assessment tool as recommended by The Cochrane Handbook of Systematic Reviews of Interventions [25]. Disagreement in data extraction and risk of bias assessment between the two authors was resolved by discussion. Agreement between the two reviewers (A.I., M.A.) on study inclusion and quality assessment was assessed by means of the kappa statistic. 


\subsection{Data Synthesis and Analysis}

We assessed the risk of infectious events utilizing extracted dichotomous data of either infection or none. A serious infection was predefined as one requiring hospital admission or intravenous antibiotic administration. If trials did not report a definition of serious infection, we extracted adverse events reported by authors as "serious infection" or "severe infection" and analyzed both as serious infectious adverse events. We calculated the risk ratio (RR) of infection and presented results with their related $95 \%$ confidence intervals (CI) as forest plots using a random effect model that utilized the Mantle-Haenzsel statistical method. The level of significance set in our analysis was $p=0.05$. Statistical heterogeneity among included studies was assessed by means of the $I^{2}$ statistic. We classified heterogeneity into three main groups (considerable heterogeneity if $I^{2}>75 \%$, significant if $>50 \%$, or low if $<50 \%$ ) in accordance with the general guidance provided in The Cochrane Handbook of Systematic Reviews of Interventions [25]. Publication bias was assessed using funnel plots. All analyses were performed using Revman (Version 5.3, The Nordic Cochrane Centre, The Cochrane Collaboration, Copenhagen, Denmark) [26]. Pre-specified subgroup analyses were performed to explore differences in infectious adverse events among various conditions (IRDs), methotrexate doses ( $<$ or $>15 \mathrm{mg}$ weekly), and study sizes ( $<$ or $>100$ participants). The attributable risk of infection and quality of evidence were assessed in accordance with the GRADE quality of evidence assessment process utilizing GRADE Pro GDT software.

\subsection{Management of Missing Data}

We chose to review and analyze the published data of relevant studies. We did not attempt to contact study authors where data were missing or not sufficiently reported.

\section{Results}

\subsection{Literature Search}

Our initial literature search retrieved 24,411 records-17,773 after removal of duplicates. Screening of the titles and abstracts resulted in the further exclusion of 17,473 articles, leaving 299 articles deemed suitable for a secondary eligibility assessment through a secondary detailed review of the full-text articles. This examination led to the exclusion of a further 286 records, leaving 13 for inclusion in our final review and analysis. Based on our eligibility criteria, the inflammatory rheumatic conditions (IRDs) that were included in this review were rheumatoid arthritis (RA), psoriasis, psoriatic arthritis (PsA), ankylosing spondylitis (AS), systemic sclerosis, and Crohn's disease. All other retrieved IRD trials did not meet our pre-specified inclusion and exclusion criteria. The agreement between reviewers for study inclusion was excellent (kappa statistic 0.958). Details of the search results, study selection and review reporting are shown below in the PRISMA flow diagram (Figure 1) and PRISMA checklist (Table S2) in the supplement.

\subsection{Study Characteristics}

Of the trials included in this review, 12 assessed the risk of infection of methotrexate versus placebo, enrolling 1146 participants, and 10 assessed the risk of serious infection, enrolling 906 participants. Serious infectious adverse events were extracted based on trial reported terms "serious infection" or "severe infection", but in most of these reports a definition of "serious" or "severe" infection was not stated. Trial durations ranged between 3 and 24 months with an enrolled number of participants of 18 to 482 . The included studies comprised five different diseases (IRDs): five trials assessed participants with psoriasis or psoriatic arthritis (PsA), three assessed RA, two assessed systemic sclerosis, two assessed ankylosing spondylitis (AS), and one assessed Crohn's disease. The range of mean ages of participants across the included trials was 33 to 59 years. All trials assessed a weekly methotrexate dose that ranged between $5 \mathrm{mg}$ and $25 \mathrm{mg}$, with three trials assessing intra-muscular therapy and the remaining ten trials assessing oral therapy. The overall risk of bias 
across studies was deemed low. Only three trials were considered at risk of bias, with a "high risk" decision made across more than one domain (Figures S1 and S2 in Supplement). The agreement between reviewers for quality assessment was very good (kappa statistic 0.826 ). Overall, while there was heterogeneity between studies as noted above with different diseases, agents, and dosing regimens, the $I^{2}$ value was $<10 \%$ for all subsequent analyses. Details of the study characteristics are shown below in Table 1.

Table 1. Characteristics of included studies on the risk of infection from methotrexate therapy in inflammatory diseases.

\begin{tabular}{|c|c|c|c|c|c|c|c|c|c|}
\hline Study & $\begin{array}{l}\text { Sample } \\
\text { Size }\end{array}$ & $\begin{array}{l}\text { Average } \\
\text { Age (y) }\end{array}$ & $\begin{array}{l}\text { Gender } \\
\text { Female } \\
(\%)\end{array}$ & $\begin{array}{l}\text { Trial } \\
\text { Duration } \\
\text { (Weeks) }\end{array}$ & $\begin{array}{l}\text { Inflammatory } \\
\text { Disease }\end{array}$ & $\begin{array}{c}\text { Severity } \\
\text { of } \\
\text { Disease }\end{array}$ & 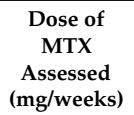 & $\begin{array}{c}\text { Route of } \\
\text { Administration }\end{array}$ & $\begin{array}{l}\text { Risk of } \\
\text { Bias } 1\end{array}$ \\
\hline $\begin{array}{c}\text { Das et al., } 2005 \\
\text { [27] }\end{array}$ & 18 & 33 & 16 & 72 & $\mathrm{SSc}^{2}$ & $\begin{array}{c}\text { Not } \\
\text { specified }\end{array}$ & 15 & $\mathrm{PO}^{3}$ & Serious \\
\hline $\begin{array}{l}\text { Feagan et al., } \\
2000[28]\end{array}$ & 76 & 33 & 60 & 40 & Crohn's & $\begin{array}{l}\text { Chronic } \\
\text { active } \\
\text { Crohn's }\end{array}$ & 15 & $\mathrm{IM}^{4}$ & Low \\
\hline $\begin{array}{c}\text { Furst et al., } \\
1989 \text { [29] }\end{array}$ & 46 & 55 & 63 & 18 & $\mathrm{RA}^{5}$ & $\begin{array}{c}\text { Not } \\
\text { specified }\end{array}$ & $7.5-15$ & $\mathrm{PO}$ & Low \\
\hline $\begin{array}{l}\text { Gonzalez-Lopez } \\
\text { et al., } 2004 \text { [30] }\end{array}$ & 35 & 35 & 31 & 24 & $\mathrm{AS}^{6}$ & Active AS & 7.5 & $\mathrm{PO}$ & Low \\
\hline $\begin{array}{l}\text { Kingsley et al., } \\
2012[31]\end{array}$ & 221 & 48 & 44 & 24 & $\mathrm{PsA}^{7}$ & $\begin{array}{c}\text { Not } \\
\text { specified }\end{array}$ & 7.5 & $\mathrm{PO}$ & Low \\
\hline $\begin{array}{l}\text { Roychowdhury } \\
\text { et al., } 2002 \text { [32] }\end{array}$ & 30 & 44 & 13 & 24 & AS & $\begin{array}{c}\text { Severe } \\
\text { active AS }\end{array}$ & 10 & $\mathrm{PO}$ & Serious \\
\hline $\begin{array}{l}\text { Saurat et al., } \\
2008 \text { [33] }\end{array}$ & 271 & 42 & 34 & 16 & Psoriasis & $\begin{array}{l}\text { Moderate } \\
\text { to severe } \\
\text { psoriasis }\end{array}$ & 7.5 & $\mathrm{PO}$ & Low \\
\hline $\begin{array}{c}\text { Singh et al., } \\
2015 \text { [34] }\end{array}$ & 81 & 39 & $\begin{array}{c}\text { Not } \\
\text { specified }\end{array}$ & 12 & Psoriasis & $\begin{array}{l}\text { Severe } \\
\text { psoriasis }\end{array}$ & $>15$ & $\mathrm{PO}$ & Serious \\
\hline $\begin{array}{c}\text { Strand et al., } \\
1999 \text { [35] }\end{array}$ & 482 & 54 & 73 & 52 & RA & $\begin{array}{l}\text { Active } \\
\text { RA }\end{array}$ & 7.5 & $\mathrm{PO}$ & Low \\
\hline $\begin{array}{c}\text { Van Den } \\
\text { Hoogen et al., } \\
1996 \text { [36] }\end{array}$ & 29 & 54 & 71 & 24 & SSc & $\begin{array}{c}\text { Not } \\
\text { specified } \\
\text { (duration } \\
\text { less than } \\
3 \text { years) }\end{array}$ & 15 & IM & Low \\
\hline $\begin{array}{l}\text { Warren et al., } \\
2017 \text { [37] }\end{array}$ & 120 & 45 & 21 & 16 & Psoriasis & $\begin{array}{l}\text { Moderate } \\
\text { to severe } \\
\text { psoriasis }\end{array}$ & 17.5 & IM & Low \\
\hline $\begin{array}{c}\text { Weinblat et al., } \\
1985 \text { [38] }\end{array}$ & 35 & 59 & 71 & 24 & RA & $\begin{array}{c}\text { Not } \\
\text { specified }\end{array}$ & $7.5-15$ & $\mathrm{PO}$ & Low \\
\hline $\begin{array}{c}\text { Willkens et al., } \\
1984 \text { [39] }\end{array}$ & 37 & 45 & 59 & 12 & PsA & $\begin{array}{c}\text { Not } \\
\text { specified }\end{array}$ & 5 & $\mathrm{PO}$ & Low \\
\hline
\end{tabular}

1: The Cochrane Risk of Bias Tool, ${ }^{2}$ : Systemic sclerosis, ${ }^{3}$ : Oral route, ${ }^{4}$ : Intramuscular route, ${ }^{5}$ : Rheumatoid arthritis,

6: Ankylosing spondylitis, ${ }^{7}$ : Psoriatic arthritis. 


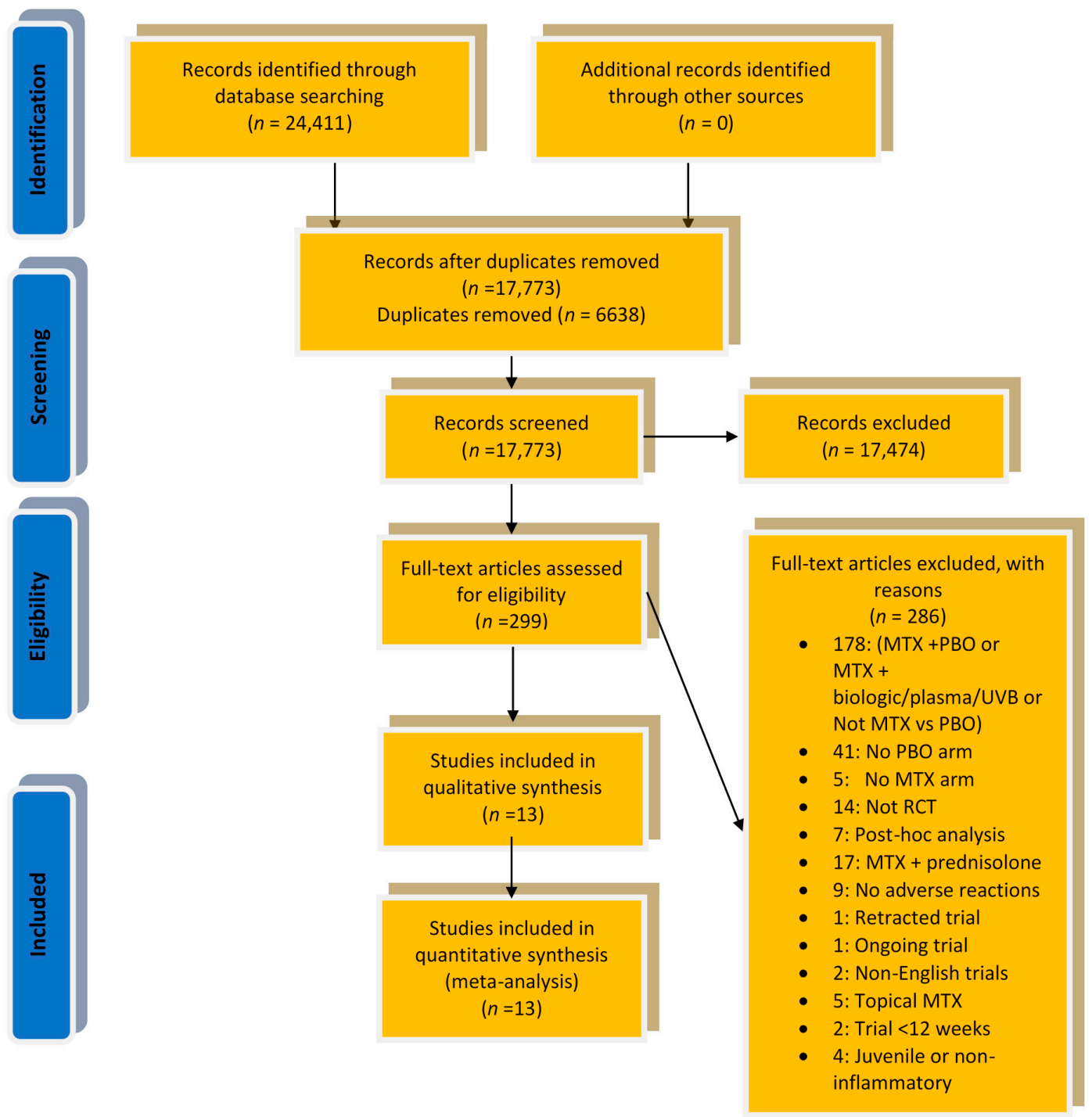

Figure 1. PRISMA flow diagram: Risk of infection of methotrexate therapy in inflammatory diseases (abbreviations: MTX—Methotrexate, PBO—Placebo, RCT—Randomized Controlled trial, UVB: Ultra violet B).

\subsection{Risk of Infectious Adverse Events and Related Subgroup Analyses}

Overall, there was no increased risk of total and serious infection associated with methotrexate therapy in inflammatory rheumatic diseases (IRDs) with relative risks of RR: 1.14 (95\% CI, 0.98-1.34; $\left.p=0.10 ; I^{2}=0 \%\right)$ and RR: $0.76\left(95 \% C I, 0.11-5.15 ; p=0.78 ; I^{2}=0 \%\right)$, respectively (Figures 2 and 3 ). Methotrexate use compared to placebo was associated with increased risk of infection in RA (RR: 1.25; 95\% CI, 1.01-1.56; $p=0.04 ; I^{2}=0 \%$ ) (Figure 4), but not in other non-RA IRD populations (RR: $1.03 ; 95 \%$ CI, $0.82-1.30 ; p=0.79 ; I^{2}=0 \%$ ) (Figure 5). It was not possible to calculate the risk of death secondary to infection or provide a breakdown of infectious events by disease severity, and the only subtype of infection assessed was respiratory infections, due to a lack of sufficient published data in trial reports. There was no increased risk of respiratory infections (RR: $0.99 ; 95 \% \mathrm{CI}, 0.73-1.33 ; p=0.94 ; I^{2}=3 \%$ ) (Figure 4).

\subsection{Further Subgroup Analyses}

Further analysis of the risk of infection in inflammatory rheumatic diseases (IRDs) was performed on subgroups based on individual diseases, dose of methotrexate ( $<$ or $>15 \mathrm{mg}$ weekly), and size 
of trials (Figure 4). The analysis evaluating the dose showed an increased risk of infection with participants taking doses of $15 \mathrm{mg}$ per week (RR: 1.24;95\% CI, $1.00-1.55 ; p=0.05 ; I^{2}=0 \%$ ), but not with those on higher doses (RR: $0.98 ; 95 \%$ CI, $0.75-1.27 ; p=0.85 ; I^{2}=0 \%$ ) (Figure 4). Methotrexate use was not associated with increased risk of infection in the subgroup of trials that had more than 100 participants (RR: $1.15 ; 95 \%$ CI, $0.98-1.36 ; p=0.09 ; I^{2}=0 \%$ ) or in those with less than 100 participants (RR: $1.02 ; 95 \%$ CI, $0.56-1.86 ; p=0.94 ; I^{2}=0 \%$ ) (Figure 4 ).

\subsection{Additional Analyses}

The absolute (excess) risk analysis of infection attributable to methotrexate therapy versus placebo was generated using Grade Pro GDT software. This showed that 88 more patients with RA treated with methotrexate per 1000 will develop an infection compared to placebo ( $95 \% \mathrm{CI}$, from 4 more to 198 more), while only 7 additional infectious adverse events per 1000 are attributed to methotrexate therapy in non-RA IRD patients (95\% CI, from 43 fewer to 72 more). Funnel plot analysis of the risk of infection with methotrexate in inflammatory rheumatic diseases (IRDs) showed no evidence of a publication bias (Figure S3 in supplement). The overall quality of evidence synthesized from this review for evaluating the primary outcome as generated by the GRADE Pro GDT online software was moderate (Table S3 in the supplement).

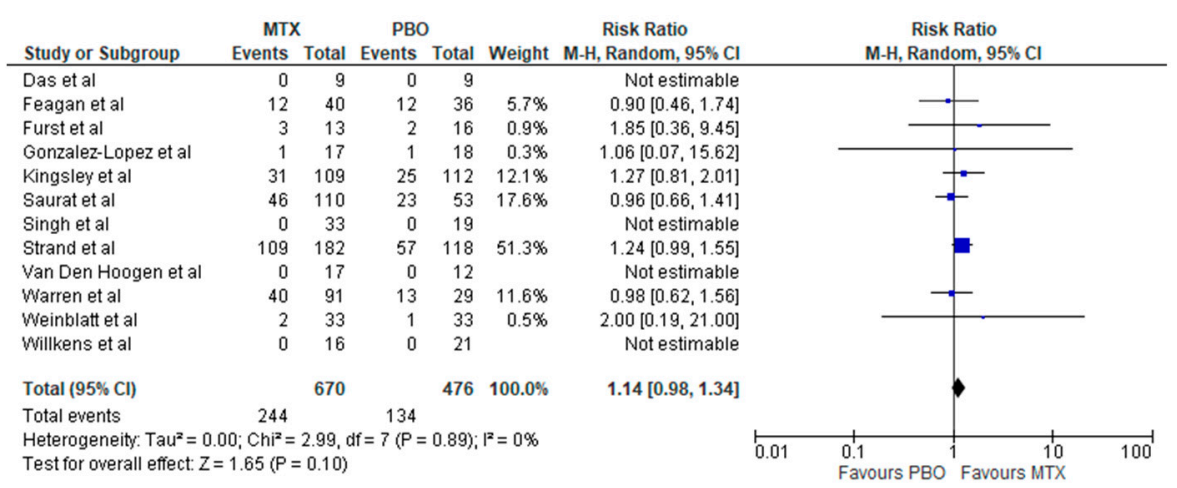

Figure 2. Forest plot: Risk of infection of methotrexate therapy in inflammatory diseases (abbreviations: MTX—methotrexate, PBO—placebo) (Studies included: [27-31,33-39]).

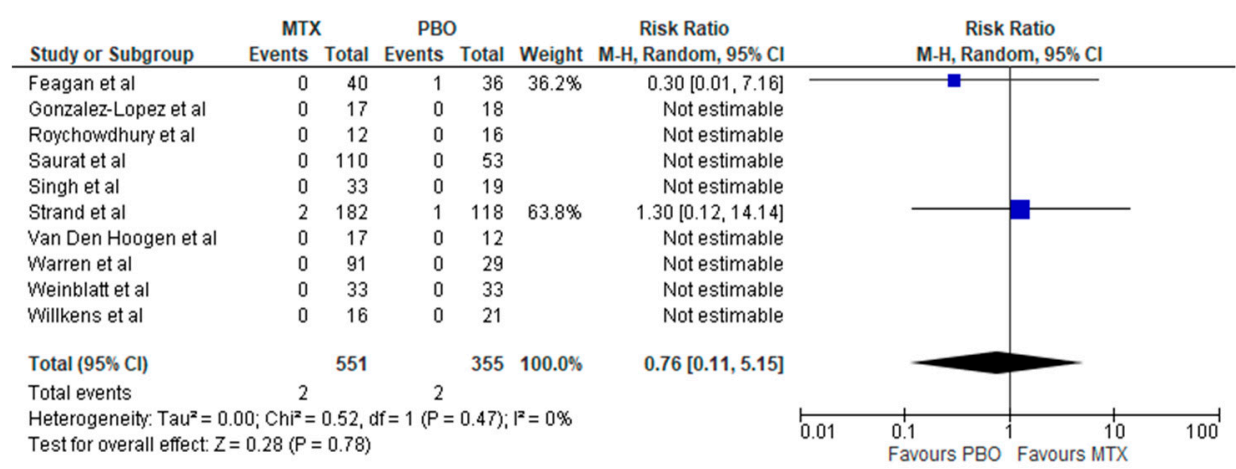

Figure 3. Forest plot: risk of serious infection of MTX vs PBO in inflammatory diseases (Studies included: $[28,30,32-39])$. 


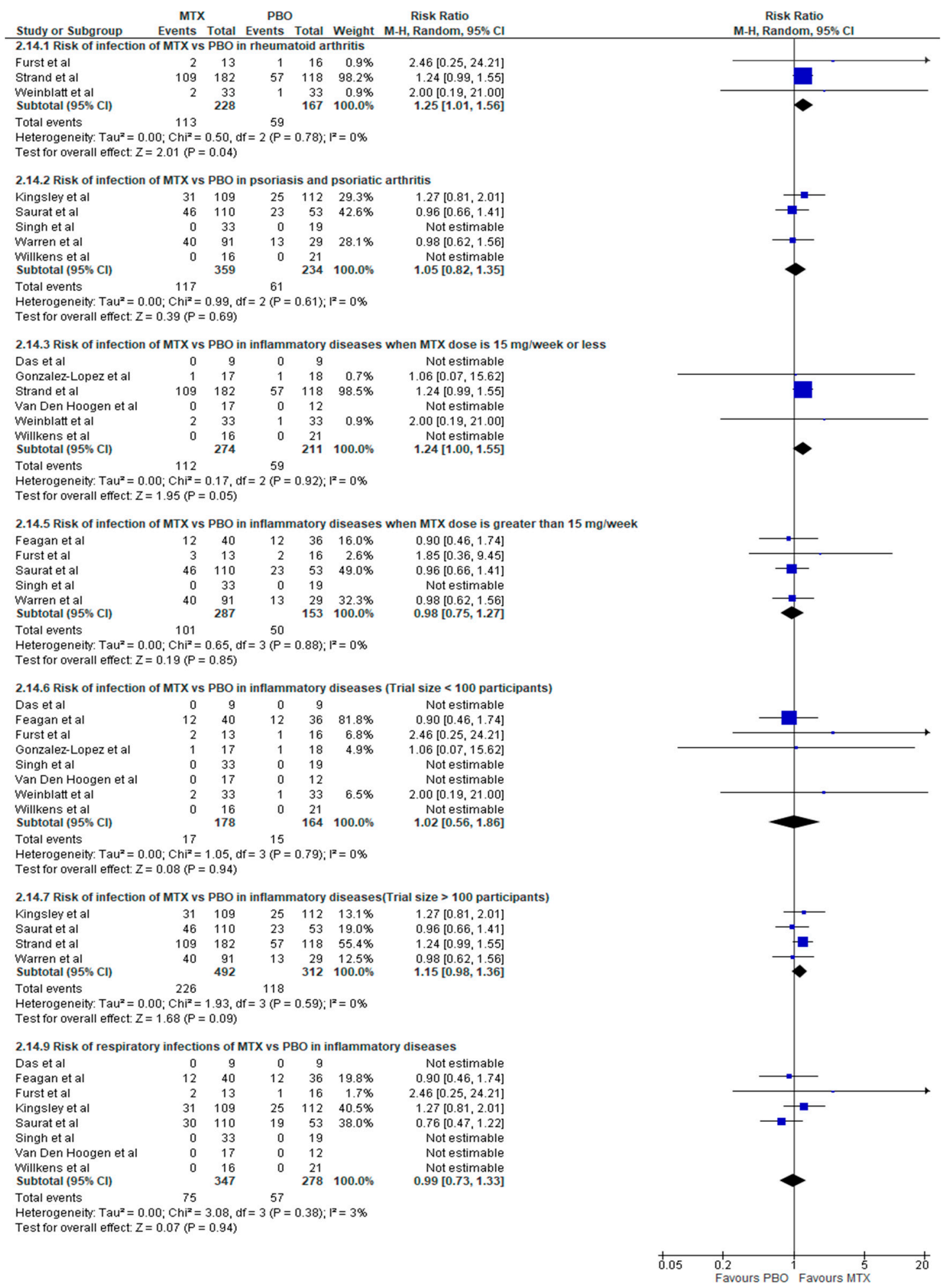

Figure 4. Forest plot: Subgroup analyses in risk of infection with methotrexate therapy in inflammatory diseases (Studies included: [27-31,33-39]). 


\begin{tabular}{|c|c|c|c|c|c|c|c|c|c|c|}
\hline Study or Subgroup & \multicolumn{2}{|c|}{ MTX } & \multicolumn{2}{|c|}{ PBO } & \multicolumn{3}{|c|}{ Risk Ratio } & \multicolumn{2}{|c|}{$\begin{array}{c}\text { Risk Ratio } \\
\text { M-H, Random, } 95 \% \mathrm{Cl}\end{array}$} & \\
\hline Das et al & 0 & 9 & 0 & 9 & & Not estimable & & & & \\
\hline Feagan et al & 12 & 40 & 12 & 36 & $12.1 \%$ & $0.90[0.46,1.74]$ & & & & \\
\hline Gonzalez-Lopez et al & 1 & 17 & 1 & 18 & $0.7 \%$ & $1.06[0.07,15.62]$ & & & & \\
\hline Kingsley et al & 31 & 109 & 25 & 112 & $25.5 \%$ & $1.27[0.81,2.01]$ & & & & \\
\hline Saurat et al & 46 & 110 & 23 & 53 & $37.1 \%$ & $0.96[0.66,1.41]$ & & & & \\
\hline Singh et al & 0 & 33 & 0 & 19 & & Not estimable & & & & \\
\hline Van Den Hoogen et al & 0 & 17 & 0 & 12 & & Not estimable & & & & \\
\hline Warren et al & 40 & 91 & 13 & 29 & $24.5 \%$ & $0.98[0.62,1.56]$ & & & & \\
\hline Willkens et al & 0 & 16 & 0 & 21 & & Not estimable & & & & \\
\hline Total $(95 \% \mathrm{Cl})$ & & 442 & & 309 & $100.0 \%$ & $1.03[0.82,1.30]$ & & & & \\
\hline Total events & 130 & & 74 & & & & & & & \\
\hline $\begin{array}{l}\text { Heterogeneity: } \operatorname{Tau}^{2}=0 \\
\text { Test for overall effect: } Z\end{array}$ & $\begin{array}{l}00 ; \mathrm{Chi}^{2}= \\
0.26(\mathrm{P}=\end{array}$ & $\begin{array}{l}1.17,0 \\
=0.79)\end{array}$ & $f=4(P=$ & 0.88 ; & $I^{2}=0 \%$ & & 0.01 & $\begin{array}{l}1 \\
0.1 \\
\text { Favours PBO }\end{array}$ & $\begin{array}{r}10 \\
\text { Favours MTX }\end{array}$ & $\overrightarrow{100}$ \\
\hline
\end{tabular}

Figure 5. Forest plot: Risk of infection of methotrexate therapy in non-RA inflammatory diseases. (Studies included: $[27,28,30,31,33,34,36,37,39])$.

\section{Discussion}

We report here the infectious risk associated with methotrexate compared to placebo in inflammatory rheumatic diseases (IRDs) including rheumatoid arthritis (RA), psoriasis and psoriatic arthritis (PsA), ankylosing spondylitis (AS), systemic sclerosis (SSc), and Crohn's disease. In this study of 13 clinical trials, we found a small but significant increased risk of infection in RA, but not in other non-RA populations. There was no increased risk of total or serious infections in all inflammatory rheumatic diseases (IRDs) included in this review. In predefined analyses, we found an increased risk of infection in lower-dose methotrexate; further analyses showed that the result is due to the increased risk in RA populations rather than a dosing effect of methotrexate.

Infections are problematic for patients with inflammatory arthritis and related diseases [40], in part due to the resulting increase in morbidity and mortality [41,42], and also in trying to decide whether these represent a complication of their underlying illness, a complication of their immunosuppressive therapy, or an unrelated event. In clinical practice, it can be difficult to distinguish which of these processes is at play. Relationships can be complex, and even paradoxical, as seen with biologic drugs whereby there is an overall increased risk of infection $[16,43]$ but perhaps a lower mortality from infection [44]. Patients with rheumatic disease experiencing an acute infection are often encountered in primary care, or general hospital settings, and are hence managed by non-rheumatologists $[45,46]$. Knowledge of infection risk with methotrexate therapy is essential for these practitioners to aid in the decision to withhold, continue, or restart effective treatment, such as methotrexate.

Observational studies of methotrexate use and infection risk report inconsistent results [12,19-21,23,47-50], with several studies showing no association [12,23,47,50,51], while others report an increased risk [19-21,48,49,52-55]. Recent large meta-analyses show no major difference in the risk of serious infections between biologics and traditional DMARDs including methotrexate therapy, and no impact from the concomitant use of methotrexate in rheumatic diseases $[16,56]$. These examined trials comparing methotrexate to other DMARDs, including biologics, making a true assessment of the risk difficult. Our study findings excluded trials with other medications known to increase the risk of infection, and are in agreement with prior publications [8,24]. These results should provide some reassurance to patients and practitioners.

Previous publications suggest that patients with RA who are prescribed methotrexate may be at higher risk of respiratory infection [8], but not patients with other inflammatory diseases [24]. In this study we found that the risk of all infections was significant in RA and low-dose methotrexate. The paradoxical effect seen with low-dose methotrexate was a surprise. However, further analyses showed that this effect was due to the confounding of the presence of RA. No increased risk was seen after adjustment for the presence of RA. Studies in RA are perhaps more complex than other diseases as RA patients are at increased risk of infection $[48,49,57]$, which may lead to an overestimation of the risk of infectious outcomes related to treatment. Additionally, differentiating rheumatoid-related pneumonitis and pulmonary disease from an infection can be difficult in practice, unlike for other 
inflammatory disorders such as psoriatic arthritis (PsA), and ankylosing spondylitis (AS) [8,24,57]. The greater susceptibility to infection in RA can be explained by multiple factors including innate and adaptive immunological dysfunctions, chronic immunocompromising co-morbidities, older age population in RA, use of immune-suppressive drugs, interestingly, and bronchiectasis related to pulmonary involvement [8,57]. In our study, RA trials had a significant weight on the meta-analysis of studies, particularly among those with methotrexate doses of $<15 \mathrm{mg}$ per week. It appears that methotrexate use in RA is associated with a higher risk of infection.

A clear understanding of the benefits, risks, and cost of interventions is critical for medical practitioners and patients. Methotrexate is a drug of a relatively low cost with favorable clinical effectiveness in many inflammatory rheumatic diseases (IRDs) [58]. A recent network meta-analysis demonstrated the remarkable clinical efficacy of methotrexate therapy in rheumatoid arthritis following the examination of 158 clinical trials [3]. However, few specifically assessed the safety profile of methotrexate therapy $[8,11,24,59]$ or expanded their population to multiple diseases [60-62]. A limited number evaluated the evidence pertaining to the risk of infection and serious infection $[8,16,59,63]$. Such studies are critically important since recent reviews have shown that the perceived risk of adverse events may be significantly lower than expected $[8,11,24]$.

Our pre-specified analyses including the risk of total and respiratory infections are in agreement with other meta-analyses $[8,24,59,63]$. Recent evidence from large meta-analyses found no difference in the risk of serious infection between methotrexate naïve and experienced patients treated with biologic therapies [16,56]. Similarly, a recent review reported no significant increased risk of severe infections with methotrexate therapy [63]. We believe that the perceived risk of infectious adverse events related to methotrexate therapy in inflammatory diseases is probably lower than previously thought, supported by the evidence from this study. It may not always be appropriate, therefore, to withhold the drug, or switch to alternative DMARDs, where the actual culprit is the disease itself or an unrelated infection rather than its therapy.

Our study has several strengths. It resolves some of the inconsistency of results generated by multiple observational studies and clinical trials, and supports the evidence suggested by recent meta-analyses $[8,16,24,56,59,63]$. We captured evidence among a wider and more heterogeneous population than some prior studies limited to a single disease. The evidence is derived from multiple quality-controlled trials (RCTs) utilizing an appropriate methodology. The risk of publication bias was assessed and deemed to be low, while the overall quality of the review was moderate as based on a GRADES working group assessment. Our findings should provide some reassurance to clinicians and patients concerned about the risk of infection with this medication.

\section{Limitations}

These findings should be interpreted judiciously for several reasons. We restricted our search to trials published in the English language only. Others have suggested that this may have minimal effects on the meta-analysis results [64,65], unless there are multiple large trials in another language with very different findings. We assumed in our study that outcomes assessed were similarly defined by all clinical trials (as in serious infections) because of the lack of detailed definitions in study reports. The effect of variability (if present) in outcome definitions on the quality of evidence generated is unknown. We only used published data, as we do not have access to patient-level data from these studies (some were quite old). This limited our analyses of some outcomes such as type of infection, breakdown of incident infection by disease severity, and risk of death due to infection. There was substantial attrition noted in some included clinical trials. We evaluated a subset of five diseases encountered in clinical practice, while remaining trials in IRDs were excluded based on our pre-specified eligibility criteria limiting generalizability of evidence. Exclusion of trials with insufficiently reported adverse events is another potential source of bias. The overall relatively small final sample size in this study in comparison to recently published meta-analyses is due to the restricted comparison of methotrexate monotherapy to placebo, an added factor that could affect the applicability 
of evidence generated in this review. However, it is these small multiple studies that meta-analysis may be most appropriate for, or where there is significant variation in conclusions in prior publications. Methodological limitations associated with meta-analyses of published RCTs are encountered such as the under-reporting of adverse events, incomplete and improperly reported rare events, and statistical approaches to dealing with zero events $[25,66,67]$. We have a small number of studies, some with little representation, and so factors such as population demographics and differences in drug metabolism between individuals and trials could alter medication response relationships and affect our results [68]. Finally, we did not include studies with other DMARDs, and selection bias is inherent in all clinical trials, perhaps limiting the external validity.

\section{Conclusions}

Methotrexate use in inflammatory rheumatic diseases (IRDs) included in this review is associated with a higher risk of all infections in RA, but not in other non-RA IRD populations. There is no increased risk of serious infections. A limited number of large high-quality studies are available to support these findings.

Supplementary Materials: The following are available online: http://www.mdpi.com/2077-0383/8/1/15/s1, Table S1: Search strategy, Table S2: PRISMA checklist, Table S3: Summary of Findings and Quality of Evidence of the Primary Outcome, RA subgroup \& Respiratory Infection According to GRADE Working Group Assessment Recommendations (GRADE pro GDT), Figure S1: Risk of bias graph, Figure S2: Risk of bias summary, Figure S3: Funnel plot to assess publication bias.

Author Contributions: Conceptualization, A.I., R.C. and J.J.C.; Data curation, A.I. and M.A.; Formal analysis, A.I. and J.J.C.; Investigation, A.I.; Methodology, A.I., M.A., R.C. and J.J.C.; Project administration, A.I. and J.J.C.; Resources, A.I.; Software, A.I.; Supervision, R.C. and J.J.C.; Validation, A.I., R.C. and J.J.C.; Visualization, A.I.; Writing-Original draft, A.I. and J.J.C.; Writing—Review and editing, A.I., M.A., R.C. and J.J.C.

Funding: This research received no external funding.

Conflicts of Interest: The authors declare no conflict of interest.

\section{References}

1. Braun, J. Methotrexate: Optimizing the efficacy in rheumatoid arthritis. Ther. Adv. Musculoskelet. Dis. 2011, 3, 151-158. [CrossRef]

2. Lopez-Olivo, M.A.; Siddhanamatha, H.R.; Shea, B.; Tugwell, P.; Wells, G.A.; Suarez-Almazor, M.E. Methotrexate for treating rheumatoid arthritis. Cochrane Database Syst. Rev. 2014. [CrossRef] [PubMed]

3. Hazlewood, G.S.; Barnabe, C.; Tomlinson, G.; Marshall, D.; Devoe, D.; Bombardier, C. Methotrexate monotherapy and methotrexate combination therapy with traditional and biologic disease modifying antirheumatic drugs for rheumatoid arthritis: Abridged cochrane systematic review and network meta-analysis. BMJ 2016, 353, i1777. [CrossRef]

4. Smolen, J.S.; Landewé, R.; Bijlsma, J.; Burmester, G.; Chatzidionysiou, K.; Dougados, M.; Nam, J.; Ramiro, S.; Voshaar, M.; van Vollenhoven, R. Eular recommendations for the management of rheumatoid arthritis with synthetic and biological disease-modifying antirheumatic drugs: 2016 update. Ann. Rheum. Dis. 2017, 76, 960-977. [CrossRef] [PubMed]

5. Jeffes, E.W.; McCullough, J.L.; Pittelkow, M.R.; McCormick, A.; Almanzor, J.; Liu, G.; Dang, M.; Voss, K.; Voss, J.; Schlotzhauer, A.; et al. Methotrexate therapy of psoriasis: Differential sensitivity of proliferating lymphoid and epithelial cells to the cytotoxic and growth-inhibitory effects of methotrexate. J. Investig. Dermatol. 1995, 104, 183-188. [CrossRef] [PubMed]

6. Sakthiswary, R.; Suresh, E. Methotrexate in systemic lupus erythematosus: A systematic review of its efficacy. Lupus 2014, 23, 225-235. [CrossRef] [PubMed]

7. De Groot, K.; Rasmussen, N.; Bacon, P.A.; Tervaert, J.W.C.; Feighery, C.; Gregorini, G.; Gross, W.L.; Luqmani, R.; Jayne, D.R. Randomized trial of cyclophosphamide versus methotrexate for induction of remission in early systemic antineutrophil cytoplasmic antibody-associated vasculitis. Arthritis Rheumatol. 2005, 52, 2461-2469. [CrossRef] [PubMed] 
8. Conway, R.; Low, C.; Coughlan, R.J.; O'donnell, M.J.; Carey, J.J. Methotrexate and lung disease in rheumatoid arthritis: A meta-analysis of randomized controlled trials. Arthritis Rheumatol. 2014, 66, 803-812. [CrossRef] [PubMed]

9. Bird, P.; Griffiths, H.; Littlejohn, G. Methotrexate in rheumatoid arthritis: Efficacy and safety. J. Pharmacovigil. 2014, 2, 1000127.

10. Salliot, C.; van der Heijde, D. Long term safety of methotrexate monotherapy in rheumatoid arthritis patients: A systematic literature research. Ann. Rheum. Dis. 2008, 68, 1100-1104. [CrossRef] [PubMed]

11. Conway, R.; Low, C.; Coughlan, R.J.; O'Donnell, M.J.; Carey, J.J. Risk of liver injury among methotrexate users: A meta-analysis of randomised controlled trials. Semin. Arthritis Rheum. 2015, 45, 156-162. [CrossRef] [PubMed]

12. Doran, M.F.; Crowson, C.S.; Pond, G.R.; O'Fallon, W.M.; Gabriel, S.E. Frequency of infection in patients with rheumatoid arthritis compared with controls: A population-based study. Arthritis Rheum. 2002, 46, 2287-2293. [CrossRef] [PubMed]

13. Segal, B.H.; Sneller, M.C. Infectious complications of immunosuppressive therapy in patients with rheumatic diseases. Rheum. Dis. Clin. N. Am. 1997, 23, 219-237. [CrossRef]

14. Doran, M.F.; Crowson, C.S.; Pond, G.R.; OFallon, W.M.; Gabriel, S.E. Predictors of infection in rheumatoid arthritis. Arthritis Rheum. 2002, 46, 2294-2300. [CrossRef] [PubMed]

15. Falagas, M.E.; Manta, K.G.; Betsi, G.I.; Pappas, G. Infection-related morbidity and mortality in patients with connective tissue diseases: A systematic review. Clin. Rheumatol. 2007, 26, 663-670. [CrossRef] [PubMed]

16. Singh, J.A.; Cameron, C.; Noorbaloochi, S.; Cullis, T.; Tucker, M.; Christensen, R.; Ghogomu, E.T.; Coyle, D.; Clifford, T.; Tugwell, P.; et al. Risk of serious infection in biological treatment of patients with rheumatoid arthritis: A systematic review and meta-analysis. Lancet 2015, 386, 258-265. [CrossRef]

17. Yamanaka, H.; Askling, J.; Berglind, N.; Franzen, S.; Frisell, T.; Garwood, C.; Greenberg, J.D.; Ho, M.; Holmqvist, M.; Novelli Horne, L.; et al. Infection rates in patients from five rheumatoid arthritis (ra) registries: Contextualising an ra clinical trial programme. RMD Open 2017, 3, e000498. [CrossRef]

18. Sokka, T.; Abelson, B.; Pincus, T. Mortality in rheumatoid arthritis: 2008 update. Clin. Exp. Rheumatol. 2008, $26,35-61$.

19. Van der Veen, M.; Van der Heide, A.; Kruize, A.; Bijlsma, J. Infection rate and use of antibiotics in patients with rheumatoid arthritis treated with methotrexate. Ann. Rheum. Dis. 1994, 53, 224-228. [CrossRef]

20. Bernatsky, S.; Hudson, M.; Suissa, S. Anti-rheumatic drug use and risk of serious infections in rheumatoid arthritis. Rheumatology 2007, 46, 1157-1160. [CrossRef]

21. Antonelli, M.A.S.; Moreland, L.W.; Brick, J.E. Herpes zoster in patients with rheumatoid arthritis treated with weekly, low-dose methotrexate. Am. J. Med. 1991, 90, 295-298. [CrossRef]

22. Kanik, K.S.; Cash, J.M. Does methotrexate increase the risk of infection or malignancy? Rheum. Dis. Clin. N. Am. 1997, 23, 955-967. [CrossRef]

23. Edwards, C.J.; Cooper, C.; Fisher, D.; Field, M.; Van Staa, T.P.; Arden, N.K. The importance of the disease process and disease-modifying antirheumatic drug treatment in the development of septic arthritis in patients with rheumatoid arthritis. Arthritis Care Res. 2007, 57, 1151-1157. [CrossRef] [PubMed]

24. Conway, R.; Low, C.; Coughlan, R.J.; O'Donnell, M.J.; Carey, J.J. Methotrexate use and risk of lung disease in psoriasis, psoriatic arthritis, and inflammatory bowel disease: Systematic literature review and meta-analysis of randomised controlled trials. BMJ 2015, 350, h1269. [CrossRef] [PubMed]

25. Higgins, J.P.; Green, S. Cochrane Handbook for Systematic Reviews of Interventions; John Wiley \& Sons: Hoboken, NJ, USA, 2011; Volume 4.

26. Review Manager (RevMan) (Computer Program), Version 5.3.; The Nordic Cochrane Centre, The Cochrane Collaboration: Copenhagen, Denmark, 2014.

27. Das, S.N.; Alam, M.R.; Islam, N.; Rahman, M.H.; Sutradhar, S.R.; Rahman, S.; Khan, G.K.; Rahim, A.; Haq, S.A. Placebo controlled trial of methotrexate in systemic sclerosis. Mymensingh Med. J. MMJ 2005, 14, 71-74. [PubMed]

28. Feagan, B.G.; Fedorak, R.N.; Irvine, E.J.; Wild, G.; Sutherland, L.; Steinhart, A.H.; Greenberg, G.R.; Koval, J.; Wong, C.J.; Hopkins, M.; et al. A comparison of methotrexate with placebo for the maintenance of remission in Crohn's disease. N. Engl. J. Med. 2000, 342, 1627-1632. [CrossRef] [PubMed]

29. Furst, D.E.; Koehnke, R.; Burmeister, L.F.; Kohler, J.; Cargill, I. Increasing methotrexate effect with increasing dose in the treatment of resistant rheumatoid arthritis. J. Rheumatol. 1989, 16, 313-320. [PubMed] 
30. Gonzalez-Lopez, L.; Garcia-Gonzalez, A.; Vazquez-Del-Mercado, M.; Munoz-Valle, J.F.; Gamez-Nava, J.I. Efficacy of methotrexate in ankylosing spondylitis: A randomized, double blind, placebo controlled trial. J. Rheumatol. 2004, 31, 1568-1574. [PubMed]

31. Kingsley, G.H.; Kowalczyk, A.; Taylor, H.; Ibrahim, F.; Packham, J.C.; McHugh, N.J.; Mulherin, D.M.; Kitas, G.D.; Chakravarty, K.; Tom, B.D.; et al. A randomized placebo-controlled trial of methotrexate in psoriatic arthritis. Rheumatology 2012, 51, 1368-1377. [CrossRef] [PubMed]

32. Roychowdhury, B.; Bintley-Bagot, S.; Bulgen, D.Y.; Thompson, R.N.; Tunn, E.J.; Moots, R.J. Is methotrexate effective in ankylosing spondylitis? Rheumatology 2002, 41, 1330-1332. [CrossRef] [PubMed]

33. Saurat, J.H.; Stingl, G.; Dubertret, L.; Papp, K.; Langley, R.G.; Ortonne, J.P.; Unnebrink, K.; Kaul, M.; Camez, A. Efficacy and safety results from the randomized controlled comparative study of adalimumab vs. methotrexate vs. placebo in patients with psoriasis (CHAMPION). Br. J. Dermatol. 2008, 158, 558-566. [CrossRef] [PubMed]

34. Singh, S.K.; Rai, T. Relapse in psoriasis with two different tapering regimens of methotrexate: a randomized open-label controlled study. Indian J. Dermatol. Venereol. Leprol. 2015, 81, 144-147. [CrossRef] [PubMed]

35. Strand, V.; Cohen, S.; Schiff, M.; Weaver, A.; Fleischmann, R.; Cannon, G.; Fox, R.; Moreland, L.; Olsen, N.; Furst, D.; et al. Treatment of active rheumatoid arthritis with leflunomide compared with placebo and methotrexate. Arch. Intern. Med. 1999, 159, 2542-2550. [CrossRef] [PubMed]

36. Van den Hoogen, F.H.; Boerbooms, A.M.; Swaak, A.J.; Rasker, J.J.; van Lier, H.J.; van de Putte, L.B. Comparison of methotrexate with placebo in the treatment of systemic sclerosis: A 24 week randomized double-blind trial, followed by a 24 week observational trial. Br. J. Rheumatol. 1996, 35, 364-372. [CrossRef] [PubMed]

37. Warren, R.B.; Mrowietz, U.; von Kiedrowski, R.; Niesmann, J.; Wilsmann-Theis, D.; Ghoreschi, K.; Zschocke, I.; Falk, T.M.; Blödorn-Schlicht, N.; Reich, K. An intensified dosing schedule of subcutaneous methotrexate in patients with moderate to severe plaque-type psoriasis (METOP): A 52 week, multicentre, randomised, double-blind, placebo-controlled, phase 3 trial. Lancet 2017, 389, 528-537. [CrossRef]

38. Weinblatt, M.E.; Coblyn, J.S.; Fox, D.A.; Fraser, P.A.; Holdsworth, D.E.; Glass, D.N.; Trentham, D.E. Efficacy of low-dose methotrexate in rheumatoid arthritis. N. Engl. J. Med. 1985, 312, 818-822. [CrossRef]

39. Willkens, R.F.; Williams, H.J.; Ward, J.R.; Egger, M.J.; Reading, J.C.; Clements, P.J.; Cathcart, E.S.; Samuelson Jr, C.O.; Solsky, M.A.; Kaplan, S.B.; et al. Randomized, double-blind, placebo controlled trial of low-dose pulse methotrexate in psoriatic arthritis. Arthritis Rheum. 1984, 27, 376-381. [CrossRef]

40. Botha-Scheepers, S.A.; Sarembock, B. Infections in the management of rheumatic diseases: An update. S. Afr. Med. J. 2015, 105, 1076. [CrossRef]

41. Mikuls, T.; Saag, K.; Criswell, L.; Merlino, L.; Kaslow, R.; Shelton, B.; Cerhan, J. Mortality risk associated with rheumatoid arthritis in a prospective cohort of older women: Results from the iowa women's health study. Ann. Rheum. Dis. 2002, 61, 994-999. [CrossRef]

42. Myllykangas-Luosujarvi, R.; Aho, K.; Kautiainen, H.; Isomaki, H. Shortening of life span and causes of excess mortality in a population-based series of subjects with rheumatoid arthritis. Clin. Exp. Rheumatol. 1995, 13, 149-153.

43. Kourbeti, I.S.; Ziakas, P.D.; Mylonakis, E. Biologic therapies in rheumatoid arthritis and the risk of opportunistic infections: A meta-analysis. Clin. Infect. Dis. 2014, 58, 1649-1657. [CrossRef] [PubMed]

44. Richter, A.; Listing, J.; Schneider, M.; Klopsch, T.; Kapelle, A.; Kaufmann, J.; Zink, A.; Strangfeld, A. Impact of treatment with biologic dmards on the risk of sepsis or mortality after serious infection in patients with rheumatoid arthritis. Ann. Rheum. Dis. 2016, 75, 1667-1673. [CrossRef] [PubMed]

45. Garneau, K.L.; Iversen, M.D.; Tsao, H.; Solomon, D.H. Primary care physicians' perspectives towards managing rheumatoid arthritis: Room for improvement. Arthritis Res. Ther. 2011, 13, R189. [CrossRef] [PubMed]

46. McGillivray, D.C. Rheumatic disease treatment services available to the family physician. Can. Fam. Phys. 1971, 17, 54-56. [PubMed]

47. Franklin, J.; Lunt, M.; Bunn, D.; Symmons, D.; Silman, A. Risk and predictors of infection leading to hospitalisation in a large primary-care-derived cohort of patients with inflammatory polyarthritis. Ann. Rheum. Dis. 2007, 66, 308-312. [CrossRef] [PubMed]

48. Coyne, P.; Hamilton, J.; Heycock, C.; Saravanan, V.; Coulson, E.; Kelly, C.A. Acute lower respiratory tract infections in patients with rheumatoid arthritis. J. Rheumatol. 2007, 34, 1832-1836. [PubMed] 
49. Smitten, A.L.; Choi, H.K.; Hochberg, M.C.; Suissa, S.; Simon, T.A.; Testa, M.A.; Chan, K.A. The risk of hospitalized infection in patients with rheumatoid arthritis. J. Rheumatol. 2008, 35, 387-393.

50. Lacaille, D.; Guh, D.P.; Abrahamowicz, M.; Anis, A.H.; Esdaile, J.M. Use of nonbiologic disease-modifying antirheumatic drugs and risk of infection in patients with rheumatoid arthritis. Arthritis Care Res. 2008, 59, 1074-1081. [CrossRef]

51. Wolfe, F.; Caplan, L.; Michaud, K. Treatment for rheumatoid arthritis and the risk of hospitalization for pneumonia: Associations with prednisone, disease-modifying antirheumatic drugs, and anti-tumor necrosis factor therapy. Arthritis Rheumatol. 2006, 54, 628-634. [CrossRef]

52. LeMense, G.; Sahn, S.A. Opportunistic infection during treatment with low dose methotrexate. Am. J. Respir. Crit. Care Med. 1994, 150, 258-260. [CrossRef]

53. Agnes, M.T.; Kerstens, P.J.; van Loenhout, J.W.; Mulder, J.; van de Putte, L.B. Infections during low-dose methotrexate treatmentin rheumatoid arthritis. Semin. Arthritis Rheum. 1995, 24, 411-421.

54. O'Reilly, S.; Hartley, P.; Jeffers, M.; Casey, E.; Clancy, L. Invasive pulmonary aspergillosis associated with low dose methotrexate therapy for rheumatoid arthritis: A case report of treatment with itraconazole. Tuber. Lung Dis. 1994, 75, 153-155. [CrossRef]

55. Saha, M.; Shipley, D.; McBride, S.; Kennedy, C.; Vega-Lopez, F. Atypical cutaneous leishmaniasis in two patients receiving low-dose methotrexate. Br. J. Dermatol. 2006, 155, 830-833. [CrossRef] [PubMed]

56. Strand, V.; Ahadieh, S.; French, J.; Geier, J.; Krishnaswami, S.; Menon, S.; Checchio, T.; Tensfeldt, T.G.; Hoffman, E.; Riese, R.; et al. Systematic review and meta-analysis of serious infections with tofacitinib and biologic disease-modifying antirheumatic drug treatment in rheumatoid arthritis clinical trials. Arthritis Res. Ther. 2015, 17, 362. [CrossRef] [PubMed]

57. Listing, J.; Gerhold, K.; Zink, A. The risk of infections associated with rheumatoid arthritis, with its comorbidity and treatment. Rheumatology 2013, 52, 53-61. [CrossRef] [PubMed]

58. Bianchi, G.; Caporali, R.; Todoerti, M.; Mattana, P. Methotrexate and rheumatoid arthritis: Current evidence regarding subcutaneous versus oral routes of administration. Adv. Ther. 2016, 33, 369-378. [CrossRef] [PubMed]

59. Mazaud, C.; Fardet, L. Relative risk of and determinants for adverse events of methotrexate prescribed at a low dose: A systematic review and meta-analysis of randomized, placebo-controlled trials. Br. J. Dermatol. 2017, 177, 978-986. [CrossRef]

60. Colebatch, A.N.; Marks, J.L.; Edwards, C.J. Safety of non-steroidal anti-inflammatory drugs, including aspirin and paracetamol (acetaminophen) in people receiving methotrexate for inflammatory arthritis (rheumatoid arthritis, ankylosing spondylitis, psoriatic arthritis, other spondyloarthritis). Cochrane Database Syst. Rev. 2011, 11, CD008872. [CrossRef]

61. Steiman, A.J.; Pope, J.E.; Thiessen-Philbrook, H.; Li, L.; Barnabe, C.; Kalache, F.; Kung, T.; Bessette, L.; Flanagan, C.; Haraoui, B.; et al. Non-biologic disease-modifying antirheumatic drugs (dmards) improve pain in inflammatory arthritis (ia): A systematic literature review of randomized controlled trials. Rheumatol. Int. 2013, 33, 1105-1120. [CrossRef]

62. Ramiro, S.; Radner, H.; van der Heijde, D.; van Tubergen, A.; Buchbinder, R.; Aletaha, D.; Landewé, R. Combination therapy for pain management in inflammatory arthritis (rheumatoid arthritis, ankylosing spondylitis, psoriatic arthritis, other spondyloarthritis). Cochrane Database Syst. Rev. 2011, 10, CD008886. [CrossRef]

63. West, J.; Ogston, S.; Foerster, J. Safety and efficacy of methotrexate in psoriasis: A meta-analysis of published trials. PLoS ONE 2016, 11, e0153740. [CrossRef]

64. Moher, D.; Pham, B.; Lawson, M.L.; Klassen, T.P. The inclusion of reports of randomised trials published in languages other than english in systematic reviews. Health Technol. Assess. 2003, 7, 1-90. [CrossRef] [PubMed]

65. Juni, P.; Holenstein, F.; Sterne, J.; Bartlett, C.; Egger, M. Direction and impact of language bias in meta-analyses of controlled trials: Empirical study. Int. J. Epidemiol. 2002, 31, 115-123. [CrossRef] [PubMed]

66. Friedrich, J.O.; Adhikari, N.K.; Beyene, J. Inclusion of zero total event trials in meta-analyses maintains analytic consistency and incorporates all available data. BMC Med. Res. Methodol. 2007, 7, 5. [CrossRef] [PubMed] 
67. Sweeting, M.J.; Sutton, A.J.; Lambert, P.C. What to add to nothing? Use and avoidance of continuity corrections in meta-analysis of sparse data. Stat. Med. 2004, 23, 1351-1375. [CrossRef] [PubMed]

68. Alomar, M.J. Factors affecting the development of adverse drug reactions. Saudi. Pharm. J. 2014, $22,83-94$. [CrossRef] [PubMed] 